\title{
Factors affecting phytoplankton extracellular release in the Southern Bight of the North Sea
}

\author{
Christiane Lancelot
}

Laboratoire d'Oceanographie, Université Libre de Bruxelles, 50, Avenue F. Roosevelt, 1050 Bruxelles, Belgium

\begin{abstract}
Phytoplankton extracellular release of organic substances was studied in the Southern Bight of the North Sea in relation to changes in growth conditions (light intensity and inorganic nitrogen concentration) and in taxonomic phytoplankton composition. Light intensity had no effect on percent extracellular release (PER). A high negative correlation between PER and mineral nitrogen concentration was found during spring bloom when phytoplankton were dominated by flagellates (Phaeocystis poucheti in the Southern Bight; dinoflagellates in the oligotrophic English Channel). The physiological response of the flagellate populations to shortage of nutrients differed. High PER was measured during the decline of the bloom with lower values in oligotrophic $(46 \%)$ than eutrophic waters $(70$ to $80 \%$ ). On the other hand, no significant correlation was found between PER and mineral nitrogen for diatoms which dominate the phytoplankton population outside the spring period. PER values were unchangeably low (0 to $14 \%$ ) over a large range of mineral nitrogen concentrations ( 0 to $50 \mu \mathrm{g}$ at $\mathrm{N} \mathrm{l}^{-1}$ ).
\end{abstract}

\section{INTRODUCTION}

Dissolved organic material released by phytoplankton may constitute an important direct source of food for microheterotrophs (Iturriaga and Hoppe, 1977; Wiebe and Smith 1977; Chrost, 1978; Lancelot, 1979; Larsson and Hagström, 1979, 1982; Wolter, 1982). It is therefore important, not only to determine accurately the rate of the excretion process, but also to understand the main environmental factors controlling it.

Since the introduction of the concept of extracellular release, both its quantitative importance and its control by environmental factors have been subject to much controversy. Some earlier studies reported high exudation rates - up to $70 \%$ of the total primary production (see the review by Sharp, 1977) - but as the ${ }^{14} \mathrm{C}$ method for measuring phytoplankton excretion was refined and the sources of error weeded out, as recommended by Sharp (1977), lower rates were generally reported. Indeed most recent data indicate that healthy, growing phytoplankton is characterized by low rates of exudation with percentage of extracellular release (PER) ranging between 0 and $10 \%$ of photosynthetic assimilation (Williams and Yentsch, 1976; Iturriaga and Hoppe, 1977; Sharp, 1977; Smith et al., 1977; Mague et al., 1980; Sellner, 1981; Larsson and Hagström, 1982).
On the other hand, most culture work shows higher rates of extracellular release when phytoplankton growth is limited either by nutrient depletion or by too high or too low light intensities (Fogg et al., 1966; Fogg, 1971, 1977; Myklestadt and Haug, 1972; Ignatiades and Fogg, 1973; Sharp, 1977).

Fogg et al. (1965) suggested that photo-assimilated carbon is released into the surrounding medium instead of being used for growth when depletion of nutrients prevents protein synthesis. According to this hypothesis, higher PER would be found in oligotrophic than in eutrophic waters. This was supported by observations of Anderson and Zeutschel (1970), Thomas (1971) and Berman and Holm-Hansen (1974); some authors found, on the contrary, lower excretion rates for oligotrophic areas (e.g. Williams and Yentsch, 1976; Sellner, 1981). Similarly, if Fogg et al.'s hypothesis is correct, higher PER would be found during the decline of a bloom in comparison with its outburst. A few works (Iturriaga and Hoppe, 1977; Smith et al., 1977; Wolter, 1982) show this, but no significant correlation between PER and nutrient concentration was found by these authors.

Part of the complexity in these observations may arise because of different physiological behaviour of the various taxonomic species which follow one 
another when environmental conditions are changing. It is known, indeed, that some different species have very different PER (Hellebust, 1965; Myklestadt, 1974; Lee and Nalewajko, 1978; Wolter, 1982), and the fact that, in most of the papers mentioned the variations in the taxonomic composition of phytoplankton have not been taken into account, can lead to misinterpretation.

In this paper, I present data on phytoplankton extracellular release in the Southern Bight of the North Sea. It will be shown that a clear picture of the effect of inorganic nitrogen - the element limiting primary production in this area (Pichot, 1980) - on this process can only be obtained by considering separately the different taxonomic groups which dominate in turn the phytoplankton community.

\section{MATERIAL AND METHODS}

\section{Collection of samples}

Most of this work was carried out in Belgian coastal waters during the spring of 1978, 1979 and 1982. In addition, samples were collected along a transect from eutrophic Belgian coastal waters to the more oligotrophic English Channel during a whole annual cycle (1982) in order to meet a large range of growth conditions. Sampled stations are shown on Fig. 1. The salinity of the studied area ranges between $30 \% \mathrm{~S}$ for the

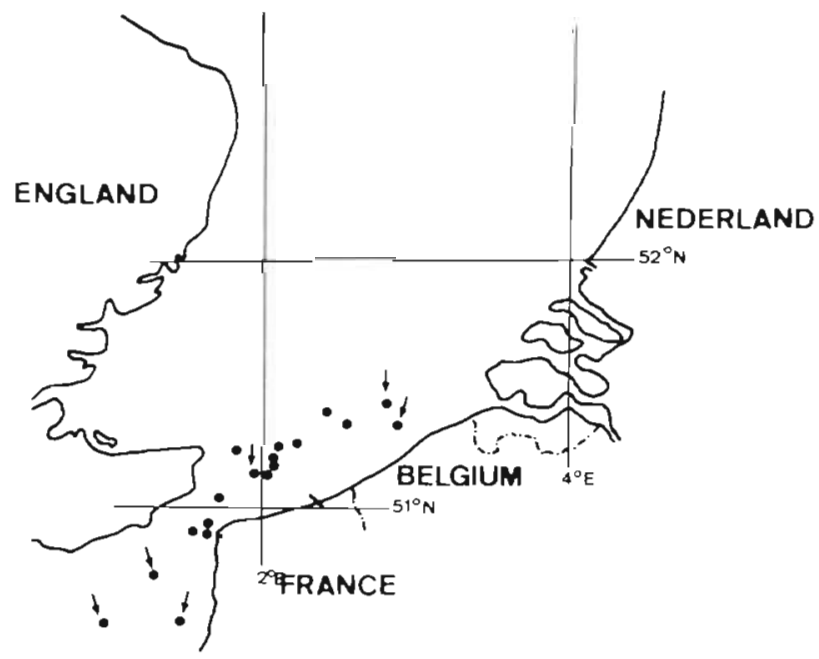

Fig. 1. Position of sampling stations. Arrows: stations chosen for studying effects of light intensity on phytoplankton excretion

most coastal stations and $35 \%$ S for stations in the Channel. Samples were collected at a depth of $3 \mathrm{~m}$ with 51 Niskin bottles; 11 was immediately filtered on $\mathrm{GF} / \mathrm{C}$ Whatman filter for chlorophyll a measurement. Filter and filtrate with 2 drops of chloroform were frozen for subsequent analysis. $100 \mathrm{ml}$ of seawater were fixed with a Lugol solution for phytoplankton cell determinations.

\section{Chemical analysis and taxonomy}

Chlorophyll a was determined spectrophotometrically following Lorenzen (1967). Ammonium was measured employing the phenol hypochlorite method (Slawyc and McIsaac, 1972). Nitrate and nitrite were determined according to Armstrong et al. (1967). Phytoplankton cells were counted after concentration by passive sedimentation in $25 \mathrm{ml}$ and $100 \mathrm{ml}$ sedimentation chambers during $24 \mathrm{~h}$, using the Utermohl procedure (1958).

\section{Photosynthesis measurements}

The classical radiocarbon method for measuring primary production (Steeman-Nielsen, 1952) was adapted to measure gross production rate of extracellular organic compounds, as a function of incubation time (Lancelot, 1979). Different sets of short-term kinetics - in vitro, in situ, in semi-situ light intensities were performed in order to examine possible effects of light intensity. In vitro and in semi-situ kinetic experiments were run in seawater-cooled incubators illuminated either by artificial constant light intensity (11500 LUX) or by natural light. Various light intensities were obtained by covering the bottles with screens of different light transmissions. In situ incubations were performed at sampling depth.

The general procedure for each kinetic study was the following: seawater was prefiltered (zooplankton net, $200 \mu \mathrm{m}$ mesh) in order to avoid excessive grazing during incubation. One hundred to $200 \mu \mathrm{Ci}$ of $\mathrm{UV}$ irradiated $\mathrm{NaH}^{14} \mathrm{CO}_{3}$ were rapidly added to 11 of prefiltered seawater. After shaking, seawater was rapidly distributed into Pyrex bottles (125 ml each), one of which was immediately filtered for zero time measurement. Bottles were then incubated for 3 to $5 \mathrm{~h}$. At short intervals, a bottle was filtered $(0.2 \mu \mathrm{m}$ Sartorius membrane filter) using a gentle vacuum (100 $\mathrm{mm} \mathrm{Hg}$ ) to avoid disruption of the cells. Filtrates and filters were collected and immediately frozen until analysis. For each kinetic experiment dark controls were checked. However, possible excretion was never measured during dark incubation. For measurements of labelled dissolved organic carbon the $\mathrm{pH}$ of the filtrate was reduced to 2 to 3 with $85 \% \mathrm{H}_{3} \mathrm{PO}_{4}$ and superfluous inorganic radioactive carbon was eliminated by bubling with air for 20 min (Kelton et al., 1977). The radioactivity contained on the filter and in the filtrate was determined by liquid scintillation. 


\section{RESULTS}

\section{Effect of light intensity}

Samples from some stations chosen along the transect (fig. 1) were incubated in semi-situ at different light intensities as described before. Phytoplankton exudation rates were given by the initial slope of the kinetic curves (Lancelot, 1979). Fig. 2 presents 2 exam-
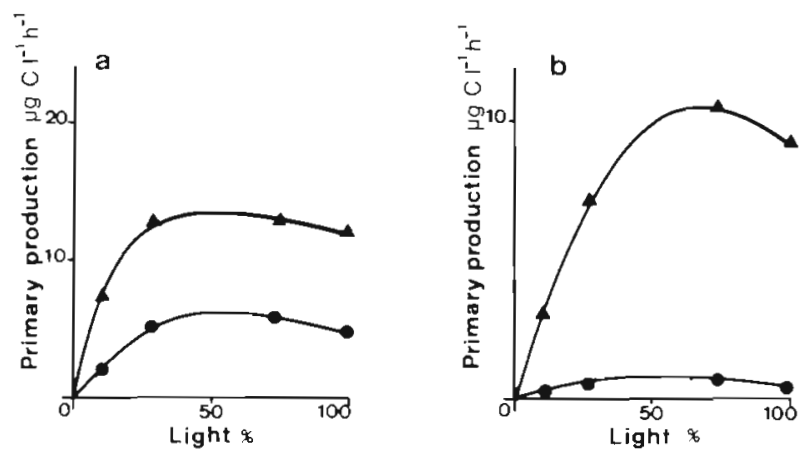

Fig. 2. Relation between rates of particulate production ( $\mathbf{A}$ ) and extracellular release $(\bullet)$, and light intensity. (a) April 1982; Station $50^{\circ} 46^{\prime} \mathrm{N} 01^{\circ} 15^{\prime} \mathrm{E}_{\text {; }}$ surface incident PhAR $=29$ joules $\mathrm{cm}^{-2} \mathrm{~h}^{-1}$. (b) June 1982; Station $51^{\circ} 15^{\prime} \mathrm{N} 02^{\circ} 13^{\prime} \mathrm{E}$; surface incident PhAR $=36$ joules $\mathrm{cm}^{-2} \mathrm{~h}^{-1}$

ples illustrating the dependence of the rates of particulate production and extracellular release on light intensity.

Results expressed in percent of the total ${ }^{14} \mathrm{C}$ fixed (PER) (Table 1 ) reveal that PER does not display any variation as a function of light intensity, regardless of the season. Even in summer, when light intensity is highest and causes photo-inhibition (Samples No 1, 5 , 6, 7, 9; Fig. 2), no significant increase of PER occurs. These results allow precise comparisons among stations, regardless of light intensity.

\section{Seasonal and geographical variations of phytoplank- tonic extracellular release}

During 5 transects from eutrophic Belgian coastal waters to the eastern English Channel, measurements of nutrient concentration and of particulate and dissolved primary production were carried out. One transect was done in winter when primary production is very low; 2 others, in the spring (including the outburst and the collapse of the phytoplanktonic bloom); the last 2 during summer and autumn.

Results of inorganic nitrogen concentration $\left(\mathrm{NO}_{3}^{-}+\right.$ $\mathrm{NO}_{2}^{-}+\mathrm{NH}_{4}^{+}$) and of phytoplanktonic extracellular release (PER) are shown in Fig. 3a, b, c, d, e. No extracellular production was found during winter although a large range of nutrient concentrations was measured (Fig. 3a). On the other hand, the spring bloom period is characterized by a large range of PER values with extremes of $5 \%$ and $80 \%$. On average, PER are higher during the decline of the bloom, when mineral nitrogen is depleted (Fig. 3c) than during early spring (Fig, 3b). Lower PER values are always found in the eastern English Channel than in eutrophic Belgian coastal waters (Fig. 3b, c).

Table 1. Effect of light intensity on percentage extracellular release (PER), expressed in \% of total primary production (particulate + dissolved)

\begin{tabular}{|c|c|c|c|c|c|c|}
\hline \multirow[b]{3}{*}{ No } & \multirow{3}{*}{$\begin{array}{c}\text { Samples } \\
\text { Co-ordinates }\end{array}$} & \multirow{3}{*}{$\begin{array}{l}\text { Surface incident } \\
\text { radiation PhAR } \\
\text { Joules } \mathrm{cm}^{-2} \mathrm{~h}^{-1}\end{array}$} & \multicolumn{4}{|c|}{ Light intensity ( $\%$ of surface incident radiation) } \\
\hline & & & 10 & 27 & 73 & 100 \\
\hline & & & $\operatorname{PER}(\%)$ & PER $(\%)$ & $\operatorname{PER}(\%)$ & PER $(\%)$ \\
\hline \multicolumn{7}{|c|}{ April } \\
\hline 1 & $50^{\circ} 46^{\prime} \mathrm{N} 01^{\circ} 15^{\prime} \mathrm{E}$ & 29 & 21 & 28 & 30 & 27 \\
\hline 2 & $50^{\circ} 33^{\prime} \mathrm{N} 00^{\circ} 54^{\prime} \mathrm{E}$ & 94 & 24 & 24 & 17 & 20 \\
\hline 3 & $51^{\circ} 09^{\prime} \mathrm{N} 01^{\circ} 57^{\prime} \mathrm{E}$ & 15 & 43 & 77 & 73 & 80 \\
\hline 4 & $51^{\circ} 24^{\prime} \mathrm{N} 02^{\circ} 48^{\prime} \mathrm{E}$ & 36 & 25 & 26 & 21 & 25 \\
\hline \multicolumn{7}{|c|}{ May } \\
\hline 5 & $50^{\circ} 33^{\prime} \mathrm{N} \quad 00^{\circ} 54^{\prime} \mathrm{E}$ & 66 & 48 & 56 & 55 & 57 \\
\hline 6 & $50^{\circ} 43^{\prime} \mathrm{N} 01^{\circ} 17^{\prime} \mathrm{E}$ & 39 & 46 & 45 & 47 & 42 \\
\hline 7 & $51^{\circ} 24^{\prime} \mathrm{N} 02^{\circ} 48^{\prime} \mathrm{E}$ & 24 & 76 & 62 & 80 & 76 \\
\hline \multicolumn{7}{|c|}{ June } \\
\hline 8 & $51^{\circ} 24^{\prime} \mathrm{N} 02^{\circ} 48^{\prime} \mathrm{E}$ & 57 & 14 & 10 & 5 & 14 \\
\hline 9 & $51^{\circ} 15^{\prime} \mathrm{N} 02^{\circ} 13^{\prime} \mathrm{E}$ & 36 & 5 & 5 & 5 & 4 \\
\hline 10 & $51^{\circ} 09^{\prime} \mathrm{N} 01^{\circ} 58^{\prime} \mathrm{E}$ & 34 & 10 & 10 & 9 & 8 \\
\hline
\end{tabular}


Outside the bloom period, relatively low PER values were measured although the level of mineral nitrogen was low. PER values range from 5 to $10 \%$ during summer (Fig. 3d) and from 0 to 14 during autumn (Fig. 3e).

\section{Effect of growing conditions on extracellular release} by successive dominant phytoplanktonic populations

Outside the spring period, the phytoplankton population (cell numbers) of the Southern Bight of the North Sea is mainly composed of diatoms. The winter period is characterized by the presence of small diatoms such as Melosira sulcata and Dimerogramma minor although large colonial forms dominate the population during summer (e.g. Rhizosolenia shrubsoler) and autumn. Only this last period includes a great variety of different coloniai diatoms.

On the other hand, during the whole spring period, phytoplankton is dominated almost exclusively $199 \%$, cell numbers) by the haptophycean Phaeocystis poucheti (Hariot) with the exception of the 2 most oligotrophic stations in the Channel where both small and large dinoflagellates are the dominant phytoplanktonic species.

One can thus regard the phytoplankton of the Southem Bight of the North Sea as being composed of only 3 types of population; for these one can study separately the effect of nutrient changes in the surrounding medium on their extracellular release (Fig. $4 a, b, c)$.

Fig. 4 a documents a significant negative correlation between PER values and inorganic nitrogen when Phaeocystis poucheti dominates the spring population. This suggests that shortage of nutrients during blooming causes increased exudation.

Although only a few data are available up to now the same type of relation between extracellular release and nitrogen concentration seems to apply to the oligotrophic dinoflagellates dominating in spring in the eastern English Channei (Fig. 4 b), but with lower values of the PER maximum. In addition Fig. $4 \mathrm{~b}$ reveals a critical inorganic nitrogen concentration beyond which all the photo-assimilated carbon is used for
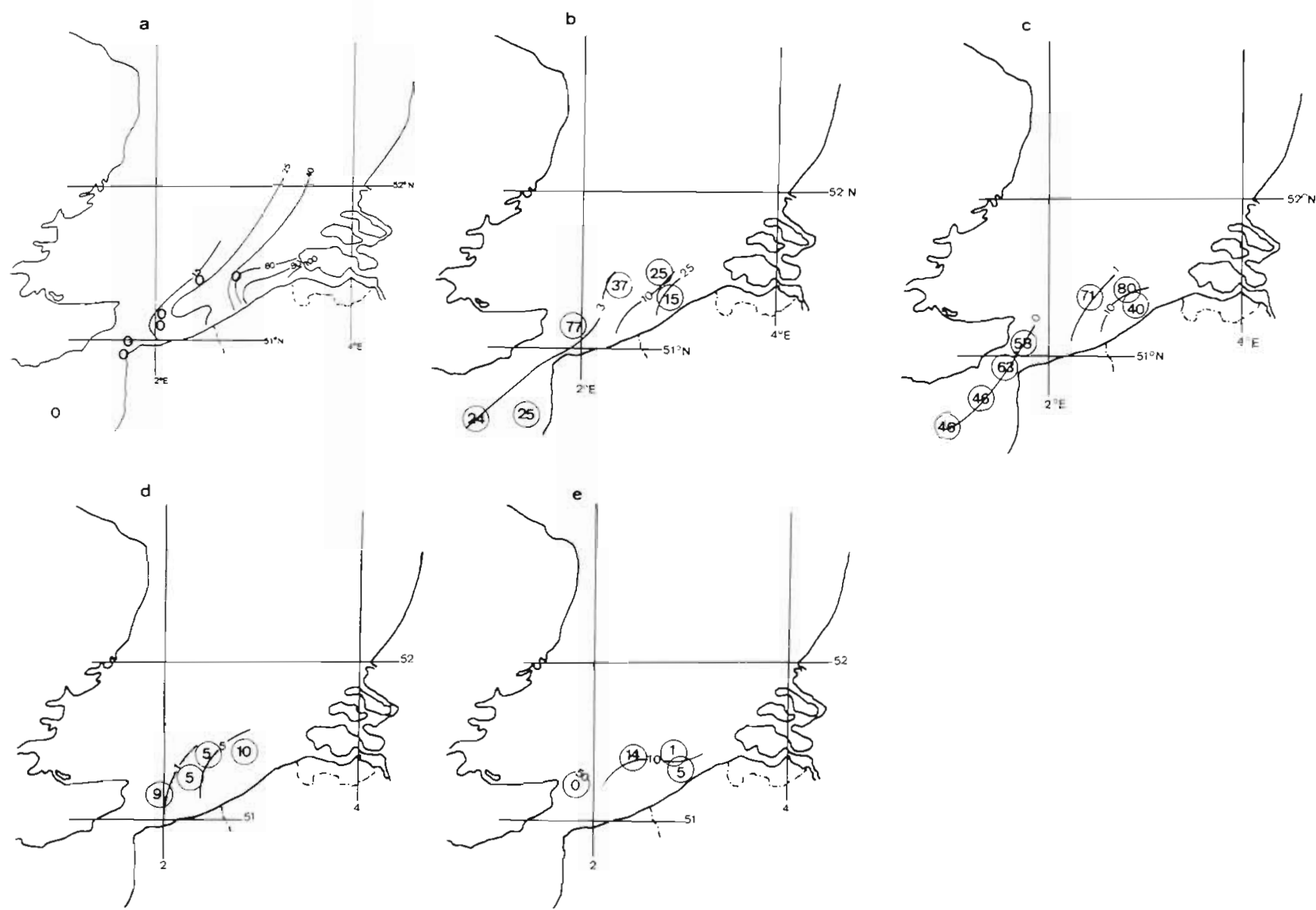

Fig. 3. Isoconcentration curves of inorganic nitrogen ( $\mu \mathrm{g}$ at $\mathrm{N}^{-1}$; geographical distribution of PER (\%). (a) winter (8 to 9 February 1982); (b) spring: outburst (20 to 23 April 1982); (c) spring: decline (19 to 21 May 1982); (d) summer (23 June 1982); (e) autumn (18 to 19 October 1982) 
intracellular biosynthesis, or respired. Such a threshold inorganic nitrogen concentration seems to exist also for the Phaeocystis community (Fig. 4a); however it was not measured.

On the other hand, no significant correlation exists between PER and nitrogen concentration for the diatom populations (Fig. 4C). PER values are always low, ranging from 0 to $14 \%$ when nitrogen ranges from 0 to $55 \mu \mathrm{g}$ at $\mathrm{NI}^{-1}$.

\section{DISCUSSION AND CONCLUSIONS}

The data presented allow the validity of some earlier concepts concerning the control of phytoplankton excretion by light intensity and nutrient concentration to be tested. The data show that the percentage of extracellular release does not depend on light intensity in the Southern Bight of the North Sea. This result agrees perfectly with that reported by Smith et al. (1977), but contrasts with most works which indicate that phytoplankton extracellular release increases relatively when primary production is limited by either low or high light intensities (Fogg et al., 1965; Hellebust, 1965; Watt, 1966; Anderson and Zeutschel, 1970; Berman and Holm-Hansen, 1974; Mague et al., 1980; Watanabe, 1980). Following these authors, PER increase at high light intensities corresponds to the release of larger amounts of glycollate produced by increased photorespiration. This process probably does not occur in the Southern Bight of the North Sea, since it has been shown that the excreted material consists mainly of large polymers ( $\mathrm{MW}>5000 \mathrm{~d}$ ) thus excluding glycollate (Lancelot, submitted).

On the other hand, the high values of PER at low light intensities reported by some authors could well result from errors due to inadequate blank corrections on very low absolute measurements of both dissolved and particulate primary production.

Several attempts (Smith et al., 1977; Mague et al., 1980; Sellner, 1982) to show the effect of nutrient concentration on extracellular release, either in seasonal or geographical surveys, remain unconvincing because changes in dominant taxonomic species were not taken into account.

My results show that, for the same range of mineral nitrogen concentration, phytoflagellates have higher PER values than diatoms. This agrees with the works of Lee and Nalewajko (1978) and Wolter (1982). Their studies suggest species-specific excretion rates and support generally greater release from flagellates than from diatoms. In addition, for each phytoflagellate population, a specific inverse relation holds between PER and mineral nitrogen concentration. This means that when nutrients decrease during a bloom because
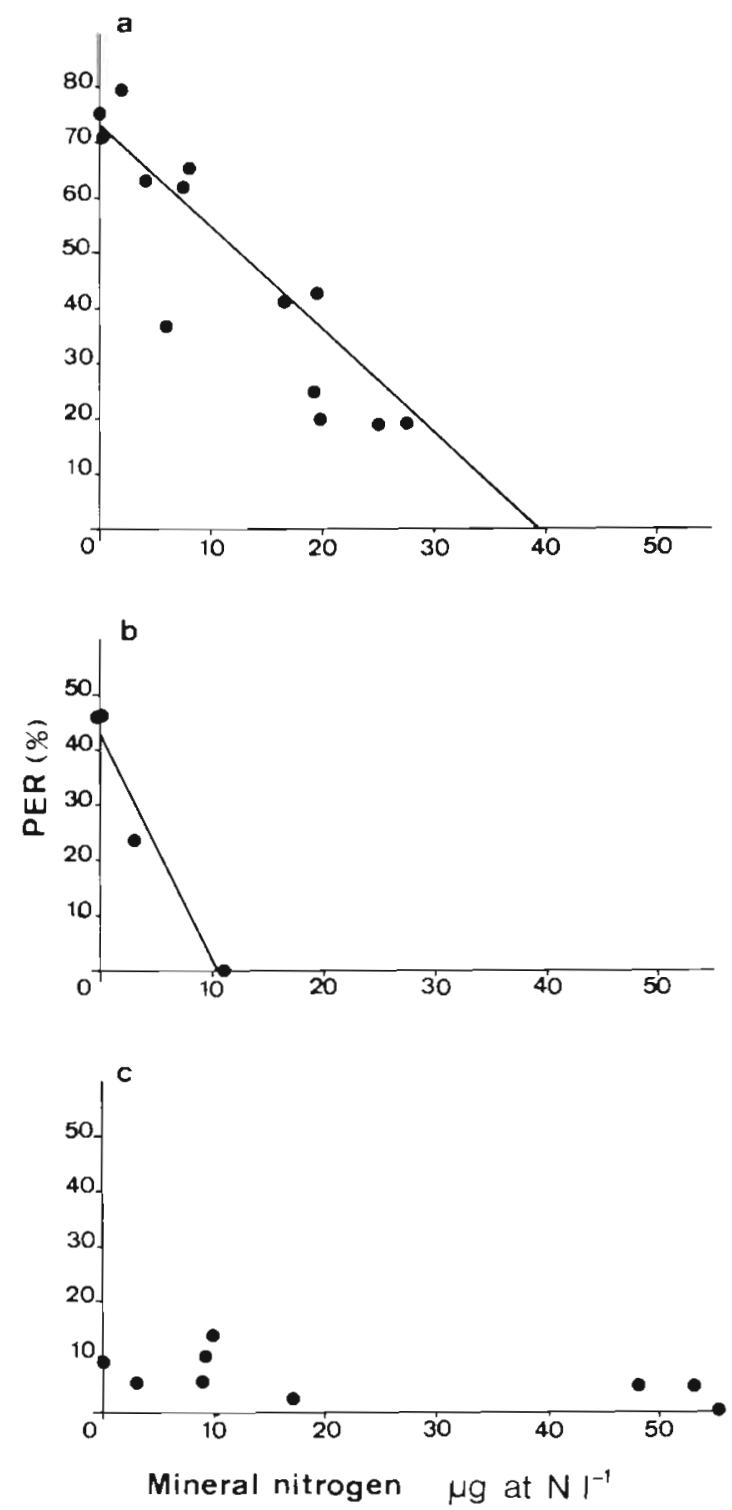

Fig. 4. Relations between PER values and inorganic nitrogen concentrations for 3 phytoplankton populations in the Southern Bight, North Sea. (a) Phaeocystis poucheti, $I=-0.91$, PER $=-2.12 \mathrm{~N}+73$; (b) dinoflagellates, $\mathrm{r}=-0.98, \mathrm{PER}=-4.10$ $\mathrm{N}+43$; (c) diatoms, $\mathrm{r}=-0.59$, not significant

of phytoplankton uptake, higher quantities of photoassimilated carbon are released into the surrounding medium in agreement with Fogg's hypothesis (Fogg et al., 1965) and other studies (Ignatiades and Fogg, 1973; Iturriaga and Hoppe, 1977; Sharp, 1977; Wolter, 1982). None of these authors, however, reported a continuous relationship, probably because of heterogeneity in phytoplanktonic species composition.

As a result of such different physiological behaviour of the 3 main groups of phytoplankton succeeding each other in the Southern Bight of the North Sea, the 
highest PER values are not found in the most oligotrophic waters as suggested by earlier works (Fogg et al., 1965; Anderson and Zeutschel, 1970; Thomas, 1971; Berman and Holm-Hansen, 1974). Outside the bloom period, PER values are very similar in oligotrophic and eutrophic waters (Fig. 3d, e), in agreement with the most recent literature (Williams and Yentsch, 1976; Sellner, 1981; Larsson and Hagström, 1982).

On the contrary, coastal waters are characterized, during the decline of the bloom, by very high PER values, never reported elsewhere in the literature. These high PER values must be attributed to the very peculiar physiology of colonial Phaeocystis poucheti which dominate the population in terms of biomass ( $99 \%$, cell numbers) during the bloom period. This species is known to synthesize a mucilage envelope during its stationary phase (Guillard and Hellebust, 1971) and this leads to the release of large quantities of extraceiliuiar products of high molecuiar weight ( $>700 \mathrm{~d}$ ) during the decline of the spring bloom.

Acknowledgements. This work was supported in part by the Ministry of Sciences Policy and by the EEC, contract ENV5S22B (R.S.). I am grateful to Dr. G. Billen for helpful criticism and to E. Stainier for nutrients determinations.

\section{LITERATURE CITED}

Anderson, G. C., Zeutschel, R. P. (1970). Release of dissolved organic matter by marine phytoplankton in coastal and offshore areas of the Northeast Pacific Ocean. Limnol. Oceanogr. 15: 402-407

Armstrong, F. A., Stems, J., Strickland, J. D. H. (1967). The measurement of upwelling and subsequent biological processes by means of the Technicon Autoanalyzer. Deep Sea Res. 14: 381-389

Berman, T., Holm-Hansen, O. (1974). Release of photoassimilated carbon as dissolved organic matter by marine phytoplankton. Mar. Biol. 28: 305-310

Chrost, R. J. (1978). The estimation of extracellular release by phytoplankton and heterotrophic activity of aquatic bacteria. Acta microbiol. pol. 27 (2): 139-146

Fogg, G. E. (1958). Extracellular products of phytoplankton and the estimation of primary production. Rapp. P.-v. Réun. Cons. perm. int. Explor. Mer 144: 56-60

Fogg, G. E. (1971). Extracellular products of algae in fresh water. Arch. Hydrobiol. 5: 1-25

Fogg, G. E. (1977). Excretion of organic matter by phytoplankton. Limnol. Oceanogr. 22 (3): 576-577

Fogg, G. E., Nalewajko, C., Watt, W. D. (1965). Extracellular products on phytoplankton photosynthesis. Proc. R. Soc. (Series B) 162: 517-534

Guillard, R. R. L., Hellebust, J. A. (1971). Growth and the production of extracellular substances by two strains of Phaeocystets poucheti. J. Phycol. 7: 330-338

Hellebust, J. A. (1965). Excretion of some organic compounds by marine phytoplankton. Limnol. Oceanogr 10: 192-206

Ignatiades, L., Fogg, G. E. (1973). Studies on the factors affecting the release of organic matter by Skeletonema costatum (Greville). Cleve in culture. J. mar. biol. Ass. U. K. 53: $937-956$
Iturriage, R., Hoppe, H. G. (1977). Observations of heterotrophic activities on photoassimilated organic matter. Mar. Biol. 40: 101-108

Kelton, R., McKinley, K. R., Ward, A. K., Wetzel, R. G. (1977). A method for obtaining more precise measures of excreted carbon. Limnol. Oceanogr. 22: 570-573

Lancelot, C. (1979). Gross excretion rates of natural marine phytoplankton and heterotrophic uptake of excreted products in the Southern North Sea, as determined by shortterm kinetics. Mar. Ecol. Prog. Ser. 1: 179-186

Lancelot, C. Extracellular release of small and large molecules by phytoplankton in the Southern Bight of the North. Sea. Submitted to Estuar. coast. mar. Sci.

Larsson, U., Hägström, A. (1979). Phytoplankton exudate release as an energy source for the growth of pelagic bacteria. Mar. Biol. 52: 199-206

Larsson, U., Hagström, A. (1982). Fractionated phytoplankton primary production, exudate release and bacterial production in a Baltic eutrophication gradient. Mar. Biol. 67; $57-70$

Lee, K., Nalewajko, C. (1978). Photosynthesis extracellular release and glycollic acid uptake by plankton: fractionation studies. Verh. int. Verein theor. angew. L.imnoi. 20: $257-262$

Lorenzen, C. J. (1967). Determination of chlorophyll and phaeopigments: spectrophotometric equations. Limnol. Oceanogr. 12: 343-347

Mague, T. H., Friberg, E., Hughes, D. J., Morris, I. (1980). Extracellular release of carbon by marine phytoplankton: a physiological approach. Limnol. Oceanogr. 25 (2): 262-279

Myklestadt, S. (1974). Production of carbohydrates by marine planktonic diatoms. I. Comparison of nine different species in culture. J. exp. mar. Biol. Ecol. 15; 261-274

Myklestadt, S., Haug, A. (1972). Production of carbohydrates by the marine diatom Chaetoceros affinis var. Willei (Gran) Hustedt. I. Effect of the concentration of nutrients in the culture medium. J. exp. mar. Biol. Ecol. 9: 125-136

Pichot, G. (1980). Simulation du cycle de l'azote à travers l'écosysteme pelagique de la Baie Sud de la mer du Nord. Thèse de doctorat. Université de Liège

Sellner, K. G. (1981). Primary productivity and the flux of dissolved organic matter in several marine environments. Mar. Biol. 65: 101-112

Sharp, J. H. (1977). Excretion of organic matter by marine phytoplankton: do healthy cells do it? Limnol. Oceanogr. 22: 381-399

Slawyc, G., McIsaac, J. J. (1972). Comparison of two automated ammonium methods in a region of coastal upwelling. Deep Sea Res. 19: 1-4

Smith, W. J., Jr., Barber, R. T., Huntsman, S. A. (1977), Primary production off the coast of Northeast Africa excretion of dissolved organic matter and its heterotrophic uptake. Deep Sea Res. 24: 35-47

Steeman-Nielsen, E. (1952). The use of radioactive carbon $\left({ }^{14} \mathrm{C}\right)$ for measuring organic production in the sea. J. Cons. perm. int. Explor. Mer 18: 117-140

Thomas, J. P. (1971). Release of dissolved organic matter from natural populations of marine phytoplankton. Mar. Biol. 11: 311-323

Utermohl, H. (1958). Zur Vervollkommnung der quantitativen Phytoplankton-Methodik. Mitt. int. Verein. theor, angew. Limnol. 9: 1-38

Watanabe, Y (1980). A study of the excretion and extracellular products of natural phytoplankton in Lake Nakanuma, Japan. Int. Revue ges. Hydrobiol. 65 (6): 809-834

Watt, W. D. (1966). Release of dissolved organic material from 
the cells of phytoplankton populations. Proc. R. Soc. (Series B). 164: 521-551

Wiebe, W. J., Smith, D. F. (1977). Direct measurement of dissolved organic carbon release by phytoplankton and incorporation by microheterotrophs. Mar. Biol. 42: 213-223

Williams, P. J., Yentsch, C.S. (1976). An examination of photosynthetic production excretion of photosynthetic products and heterotrophic utilization of dissolved organic compounds with reference to results from a coastal subtropical sea. Mar. Biol. 35: 31-40

Wolter, K. (1982). Bacterial incorporation of organic substances released by natural phytoplankton populations. Mar. Ecol. Prog. Ser. 7 (3): 287-295

This paper was submitted to the editor; it was accepted for printing on February 24,1983 